\title{
POLICY PERSPECTIVES OF MITIGATION AND RECOVERY DURING COVID-19 PANDEMIC: A NARRATIVE REVIEW
}

\author{
Perspektif Kebijakan Mitigasi dan Pemulihan Pandemi Covid-19: \\ Tinjauan Pustaka Naratif
}

*Withanage Iresha Udayangani Jayawickrama1, Weerapperuma Kankanamge Wijaya Sarathchandra Kumarawansa ${ }^{1}$, Kapu Gamage Ravindra Vishwajith Pathirathna ${ }^{1}$, Adikari Mudiyanselage Pamila Sadeeka Adikari $^{1}$, Yaddehige Jayanath Samarasinghe ${ }^{1}$

${ }^{1}$ Ministry of Health, Sri Lanka

Correspondence*

Address: Ministry of Health, Colombo, Sri Lanka | e-mail: dr.iresha@yahoo.com

\begin{abstract}
Background: The world is in the grip of an unprecedented novel COVID-19 pandemic. These have resulted in massive impacts on humans as well as on economies invariably. Hence, planning for a future pandemic is vital in minimizing deleterious effects.

Aims: The current review aimed to derive common policy perspectives that are important in future planning of a pandemic.

Methods: A narrative review was conducted by searching published articles from PubMed, Medline, Scopus, CINAHL, and Google Scholar. Forty-eight articles were selected for the review.

Results: The policy perspectives derived under mitigation were rearranged into surveillance, epidemiology, and lab activities. The policy perspectives under recovery derived were related to economy, supply chain management, sustainable and green concept, and health system.

Conclusion: Understanding common policy perspectives is important in the mitigation and recovery planning of a pandemic with similar nature in the future. The spillover effects in response to the mitigation measures are deemed vital in planning mitigation and recovery measures for future pandemics. Global and regional resource sharing mechanisms are vital when a universal shortage of healthcare resources occurs.
\end{abstract}

Keywords: mitigation, pandemic management, policy perspectives, recovery

\begin{abstract}
Abstrak
Latar Belakang: Seluruh dunia menghadapi pandemi COVID-19 yang tidak menentu. Intervensi ini telah menimbulkan dampak yang besar bagi manusia dan perekonomian. Maka, perencanaan pandemi di masa yang akan datang sangat penting untuk meminimalisir dampak buruknya.

Tujuan: Tinjauan ini bertujuan menghasilkan perspektif kebijakan umum yang penting untuk perencanaan pandemi di masa yang akan datang.

Metode: Tinjauan naratif dilakukan dengan menelusuri artikel yang terbit di PubMed, Medline, Scopus, CINAHL, dan Google Scholar. Sebanyak 48 artikel dipilih untuk diulas.

Hasil: Perspektif kebijakan yang diturunkan terkait mitigasi meliputi pengawasan, epidemiologi, dan aktivitas laboratorium. Perspektif kebijakan berkaitan dengan pemulihan ekonomi, penanggulangan rantai pasok, konsep keberlanjutan dan ramah lingkungan, serta sistem kesehatan.

Kesimpulan: Pemahaman mengenai perspektif kebijakan secara umum sangat penting untuk perencanaan mitigasi dan pemulihan pandemi dengan ciri-ciri serupa di masa yang akan datang. Dampak spillover yang berkaitan dengan langkahlangkah mitigasi dianggap penting untuk merencanakan langkah-langkah mitigasi dan pemulihan pandemi di masa yang akan datang. Mekanisme pembagian sumberdaya di tingkat regional dan global penting dilakukan saat sumberdaya pada pelayanan kesehatan tidak mencukupi.
\end{abstract}

Kata kunci: mitigasi, pemulihan, penanggulangan pandemi, perspektif kebijakan 


\section{Introduction}

In the dawn of 2020, the world has faced an unprecedented threat of COVID19 , a newly emergent virus that resulted in a pandemic COVID-19. It was originated in Wuhan, China at the end of 2019. It has spread across many continents, challenging the existing healthcare systems there (Tabish, 2020). COVID-19 has a gamut of impacts, quantifying the direct impact on human lives as of May 21st, 2020, with 5,016,171 confirmed cases and 328,471 deaths worldwide (John Hopkins University of Medicine, 2020). In response to the rising number of cases and deaths, non-pharmaceutical measures have been implemented globally in varying combinations since the therapeutics and vaccine are yet to be developed for this novel virus (S. Lai et al., 2020). The world is grappling to curb the transmission of COVID-19 with concerted efforts, though certain characteristics of the virus have made measures more complicated. The long incubation period, high transmissibility, pre-symptomatic and asymptomatic cases that infect others, and knowledge gap due to the novelty of the virus are some of the factors that largely have contributed to the apparent deleterious effects of COVID-19 (Nunesvaz, 2020).

The nature of the virus, unavailability of preventive and treatment measures, direct and indirect massive impacts COVID-19 have emphasized the need for mitigation and recovery planning for such catastrophe in the future (Douglas et al., 2020). Further, the relentless globalization and increasing global human interactions have profoundly influenced the transmission of infectious diseases potentially across distant countries, again highlighting the imperative need for national pandemic management planning (Wirth, 2018).

Mitigation mainly focuses on slowing the transmission, protecting the population and preventing the overwhelming healthcare system by executing mitigation measures at the individual level as well as at the community level (Nova Scotia Health Authority, 2020; Shearer et al., 2020). However, recovery measures have been implemented primarily in an attempt to resume normal operations through a planned and coordinated approach (Nova Scotia Health Authority, 2020). The implementation of mitigation and recovery measures was supported with the relevant public health policies that have already been available, amended, or newly developed accordingly (The Organisation for Economic Co-operation and Development, 2020). Nevertheless, heterogeneity was evident in policy options implemented in response to COVID-19 across the countries, as well as across the sectors.

The fast and untenable spread, global scale, longer disease duration, and devastating direct and indirect impacts complicate the COVID-19 policymaking process (Weible et al., 2020). In general, policymaking inexorably involves the trade-offs between social, political and ethical values, opinions, interests, and priorities (Verboom, Montgomery, and Bennett, 2016). However, the controversies, differences, and confusions observed in policy perspectives have spawned the need for pragmatic public health policies to be adopted during the COVID-19 pandemic and similar outbreaks to other potential pandemics (Weible et al., 2020). Hence, this study took a chance to review the decisions and actions undertaken for mitigation and recovery measures during the COVID-19 pandemic and identify common policy perspectives for combatting the massive effects of other pandemics globally. According to the background of the issue, the present study aimed to review the current literature on mitigation and recovery responses during the COVID-19 pandemic and derive policy perspectives deemed imperative for the preparedness of a future pandemic with common nature.

\section{Method}

\section{Literature Search}

The article search was performed on PubMed, MEDLINE, Scopus, and CINAHL. The period covered in the search was from January 2020 to May 2020. Review protocol has been used to make the process clear and consistent 
thoroughly. Database search was done manually to the lists of identified articles. Besides, some primary articles within grey literature were also discovered in Google Scholar. Further, Google search was also used to identify the relevant documents from the government institutional websites to support the scope of interest and find preprint articles due to inadequacy of peer-reviewed literature at the moment of the data collection. Search strategies were finalized with the inputs of a research librarian (Supplementary material- Search Strategies). The search terms used were Response*, Mitigation*, Recovery*, Rehabilitation*, Reconstruction*, Pandemic*, COVID-19, Coronavirus 2019, and SARS-CoV-2. Only articles including human subjects and in the English language were included in the study.

\section{Data extraction and analysis}

To identify whether articles and reports met the inclusion criteria, five review authors screened the titles, abstracts, and summaries of all retrieved records. These articles and reports were selected independently, and the results were discussed to decide on the final selection. After reading the full texts of all eligible articles and reports, a collective final decision was taken for each record. The selection process has been summarized in Figure 1
The reports published with guidance in response to COVID-19 mitigation and recovery measures were also included in the review in addition to those found in the databases. Data extraction was also performed by all five reviewers independently in a structured format. Any disagreement among the reviewers was discussed after the completion of the data collection process. Initially, sub-themes were identified, and secondly, main themes were identified amalgamating the sub-themes by all of the authors via teleconferences. Then, the common policy perspectives were synthesized by amalgamating the main themes observed mainly under COVID-19 mitigation and recovery. The results were summarized and reported in a format adopted from the Influenza pandemic plan in the United States (U.S. Department of Health and Human Services (HHS), 2017).

\section{Result and Discussion}

A total of 48 articles were included in the fi nal review. The policy perspectives that were universally discussed during mitigation were rearranged as can be seen in Table 1. The policy perspectives under COVID-19 recovery generally conversed were related to economy, supply chain management, sustainable and green concept, and health system (Table 1).

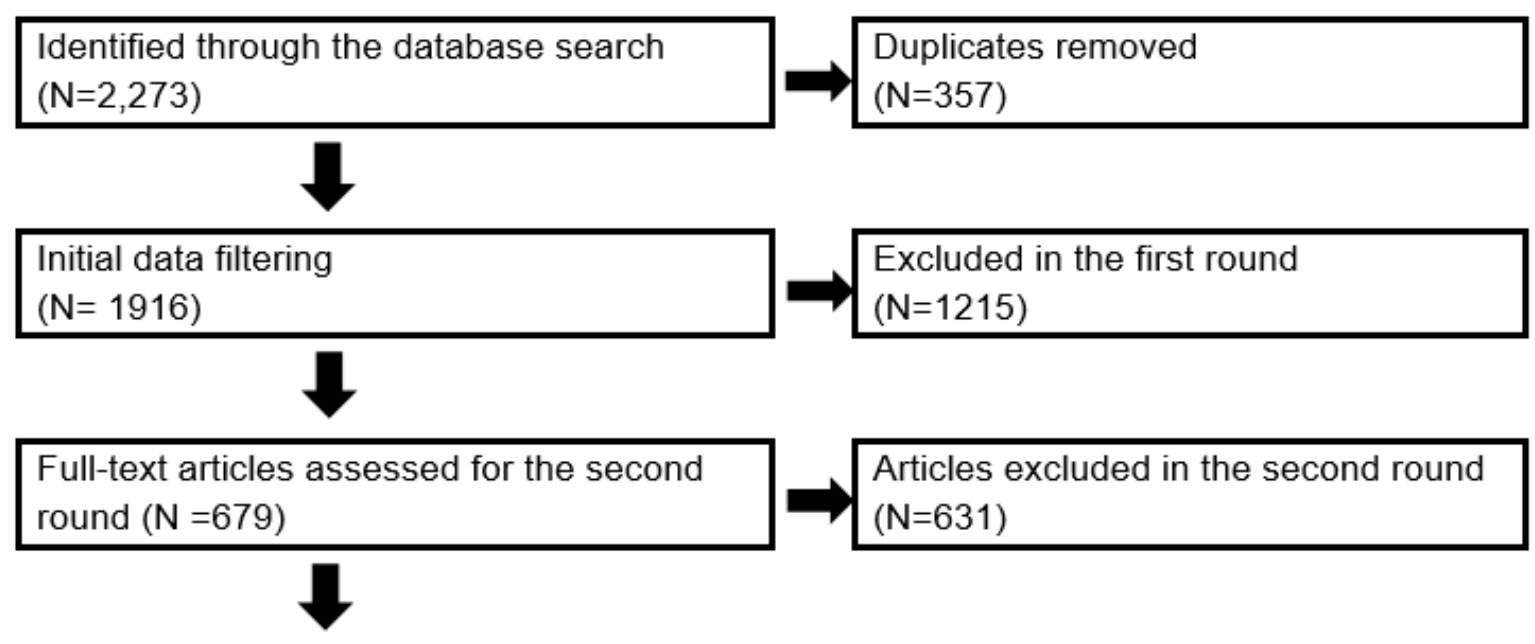

Number of articles selected for the narrative review $(\mathrm{N}=48)$

Figure 1. The selection process 
Table 1. Common Policy Perspectives in Mitigation and Recovery Phases.

\begin{tabular}{|c|c|}
\hline Phases & Policy Perspectives \\
\hline $\begin{array}{l}\text { 1. Surveillance, } \\
\text { epidemiology and } \\
\text { lab activity }\end{array}$ & $\begin{array}{l}\text { Ensure continuous supplies of laboratory test facilities, as well as } \\
\text { need regional and international policies for laboratory testing and } \\
\text { supply of resources (Walker et al., 2020) } \\
\text { Need to explore long term course of the disease to understand the } \\
\text { seasonal patterns, population herd immunity and zoonotic genome } \\
\text { changes (World Health Organization, 2020) } \\
\text { Need to consider epidemiological characteristics of the virus such as } \\
\text { virulence, infectivity, RO factors (World Health Organization, 2020) } \\
\text { Need to concern enhanced sensitivity of global surveillance and } \\
\text { response system, real-time tracking and alert system that is active } \\
\text { both regionally and globally (Desjardins, Hohl and Delmelle, 2020). }\end{array}$ \\
\hline
\end{tabular}

2. Community mitigation

measures
Need principles of population categorization when resuming back to activities to reduce exposures (Lasry et al., 2020).

Respect social and cultural values during policy development and funeral/burial/cremation guidelines (Crubézy and Telmon, 2020).

Need a strong approach for multisector, multidisciplinary policy expressions due to the wide scopes of the disease (Chen, Cao, and Yang, 2020).

Consider political bureaucracy versus social freedom in the implementation of lockdown strategies (Radwanski and Semeniuk, 2020)

Consider human rights aspects of public health measures due to negative spillover effects (Shuja et al., 2020)

Consider smart containment and mitigation measures versus lockdown measures by taking into account context-specific factors (Ebrahim et al., 2020)

Need special attention for asymptomatic case management, considering up to $80 \%$ of the cases are asymptomatic

Apply GIS and Al technology for public health measures and social cohesion (Drew et al., 2020; Kamel Boulos and Geraghty, 2020)

Need guidelines issued for public on the use of PPE (Wong et al., 2020)

Apply mitigation measures for international travel (Ebrahim et al., 2020)

Apply additional measures to prevent the disease transmission at workplaces (Anderson et al., 2020)

\section{Medical} countermeasure $\mathrm{s}$, diagnostic devices, vaccines, therapeutic, and respiratory devices
Provide continuity of medical supply chains for the PPE, ventilators and laboratory testing equipment (Bruinen de Bruin et al., 2020) Need alternative production sites for PPEs

Need global monitoring mechanisms for supply chain Encourage national production of medical supplies (Bruinen de Bruin et al., 2020; Heymann et al., 2020)
4. Healthcare system preparedness and response
Need public-private partnership in service provision (Parodi and Liu, 2020)

Transform the health sector from patient-centred to communitycentred principles. Important to identify barriers or facilitators and external effects (Nacoti et al., 2020) 
Transform leadership styles when cases surge, and need more autonomy for local and institutional level leaders (Hammer and Alley, 2020)

Need principles of population cohorting for resource allocation considering the disease and its epidemiology

Put special concerns for on the provision of PPE and training, especially on CBRN and on screening and diagnostic facilities for healthcare staff (Australian Government, Department of Health, 2020)

Identify specific workforces, such as the number of health frontline staff and other non-health-military and key workers/volunteers with the appropriate knowledge skills and abilities (Shuja et al., 2020) Reduce hospital burden and preparing hospitals for surge

Create Innovative approaches for community triage and referral to healthcare institutions (Ayebare et al., 2020; Lurie et al., 2020)

Invest in public health infrastructure (Walensky and Del Rio, 2020)

5. Communication and public outreach
Need risk communication, unique features in risk communication, such as mighty real-time, electronic-based, and trustworthy risk communication by formal authorities (Heymann et al., 2020; Igoe, 2020; Walker et al., 2020)

Place a special concern for vulnerable and high-risk groups
6. Scientific infrastructure and preparedness
Conduct research and development considering international collaboration, proactive planning and research allocation ( $\mathrm{Li}$ et al., 2020; Li, Liu, and Ge, 2020; Yip et al., 2020)
7. Need domestic and international response policies, incident management and global partnerships and capacity building
Seek for all opportunities for local, national, regional and global collaboration and funding (Simchi-Levi, Schmidt and Yehua, 2020) Consider the risk of developing political tension locally and regionally Need transparency and accountability in foreign aid management Have special legislation changes for ICT (Simchi-Levi, Schmidt and Yehua, 2020)

\section{Policy} intervention for economic recovery
Apply microfinancing for Small and Medium Enterprises (SMEs) and self- employments Baker et al., 2020

Build strong coordination between donors and development partners Establish economic recovery along with social justice and decent works (Atkenson, 2020; Buheji et al., 2020; Kohlscheen, Mojon and Rees, 2020; S. Baker et al., 2020)

Provide grants and concessional loans to Low- and middle-income countries to give more debt relief for effectively kick-starting economic recovery (Loayza and Pennings, 2020)
9. Supply chain management of goods
Focus on identifying exposure to risk associated with materials and suppliers, prioritizing and allocating resources effectively and investing in mitigation strategies (Armani et al., 2020; Cundell et al., 2020; Novak and Loy, 2020; Rowan and Laffey, 2020)

\footnotetext{
10.Investment on diagnostic, 
vaccine and

medicine

\section{Sustainable Boost the economies under sustainable green concept (Williams, and green 2017; Climate Action Tracker, 2020) \\ concept
12.Recovery of Fulfil mental health needs in frontline staff and vulnerable groups (J. mental health Lai et al., 2020; Zhang et al., 2020).
needs Build multisector coordination to provide effective services to improve mental health (Wang et al., 2020)
13.Resuming Address the need of resuming routine health services (Tabish, 2020; routine health Hunter et al., 2020) services

\begin{tabular}{cl}
\hline $\begin{array}{c}\text { 14. Health } \\
\text { Promotion }\end{array}$ & $\begin{array}{l}\text { Highlight the need for detailed understanding some risk factors such } \\
\text { as smoking and hypertension, shown to be linked with COVID-19 } \\
\text { infection in China (Engin, Engin and Engin, 2020) }\end{array}$ \\
\hline $\begin{array}{c}\text { 15.Infrastructure } \\
\text { development }\end{array}$ & $\begin{array}{l}\text { Need to escalate the investments in acute care beds and public } \\
\text { health capacity (World Health Organization, 2020) }\end{array}$ \\
\hline 16.Felicitation & $\begin{array}{l}\text { Give profound appreciation and due respect to the health workforce } \\
\text { (Walensky and Del Rio, 2020) }\end{array}$
\end{tabular}

\section{Policy perspectives for mitigation} during the COVID-19 pandemic

\section{Surveillance, epidemiology and lab activity}

Surveillance of epidemiological data is a core function in an outbreak investigation. It is necessary to have the correct information at the right time to make informed decisions and actions against the spread of an infectious disease (Nsubuga P, White ME, 2006). Epidemiological characteristics of the COVID-19 such as virulence, infectivity, and basic reproduction number are several key indicators that facilitate decision making at the global and national levels. Enhanced sensitivity of global surveillance and response with real-time tracking and alert systems that are sensitive even for a single case is identified as a priority in the pandemic mitigation including COVID-19 mitigation (Madhav et al., 2017; Desjardins, Hohl and Delmelle, 2020).
COVID-19 is anticipated to coexist with seasonal influenza and expected to result in a surge of cases with seasonal changes in temperate countries (World Health Organization, 2020). Hence, the need to explore the seasonal pattern of COVID-19, in the long run, is a concern in the preparedness of future epidemics.

Literature supported to derive the need for enhanced sensitivity of global surveillance and response system. Real-time tracking and alert system that is active both regionally and globally is one of the actions to prepare (Desjardins, Hohl and Delmelle, 2020). Epidemiological characteristics of the virus such as virulence, infectivity, R0 factors when making decisions at the central level during a pandemic shall be considered as well (World Health Organization, 2020). Another essential perspective summarized from the studies is the need to explore the long term course of the disease to understand the seasonal patterns, population herd immunity, and zoonotic genome changes (World Health Organization, 2020). It is broadly identified as 
a key policy response during the pandemic, where continuous supplies of laboratory test facilities need to be ensured, and regional and international policies for laboratory testing and supply of resources are required (Walker et al., 2020).

Further, the epidemiological factors and the assessment of the likelihood of infection are necessary for decision making related to laboratory testing due to the high transmissibility and the limited knowledge of the virus. The availability of regional and international policies for laboratory testing and measures to ensure the continuous supply of laboratory test facilities is recognized as key findings in the review (Walker et al., 2020).

\section{Community mitigation measures}

Community mitigation measures are widely being used to curb the disease spread since there are no specific therapeutics and vaccines available at the moment. Community mitigation measures, e.g., social distancing, personal protective measures, and environmental surface hygiene, and others are commonly being used to slow the virus transmission (Lasry et al., 2020). Technological development, nature of political bureaucracy, level of public compliance for advice and economic status of the country have significantly influenced the decisionmaking process in the selection of community measures.

The key policy perspectives that have been derived are smart containment and mitigation measures versus lockdown measures (Ebrahim et al., 2020); application of technology for public health measures and social cohesion (World Health Organization, 2020); guidelines issued for the public on the use of Personal Protective Equipment (PPE) (Wong et al., 2020); mitigation measures for international travel (Ebrahim et al., 2020); consideration of human rights aspects for public health measures (Shuja et al., 2020); consideration of political bureaucracy versus social freedom in implementing lockdown strategies
(Radwanski and Semeniuk, 2020); respecting social and cultural values during policy development (Crubézy and Telmon, 2020); a strong multisector approach (Chen, Cao, and Yang, 2020); and additional measures to prevent the disease at the workplace (Anderson et al., 2020). Moreover, the articles suggest smart containment measures, i.e, effective personal and public hygiene measures, protection of the most vulnerable group to the disease, isolation of infected people, telephone triaging, and effective referral system, over the lockdown measures in controlling the disease spread, especially in developing countries (Ebrahim et al., 2020).

Political bureaucracy versus social freedom is debatable in the implementation of the lockdown strategies and deemed two sides of a coin (Radwanski and Semeniuk, 2020). Hence, the selection process of the mitigation measures in a particular locality could negatively impact the expected outcome. Maintenance of transparency and trust is essential in preserving a calm response to the public measures. The public compliance depends on social, ethnic, and cultural values during policy development. The need for evidencebased, culture and religion sensitive cremation guidelines has been discussed across many regions (Crubézy and Telmon, 2020).

At the same time, extreme fear and uncertainty are brought by the pandemic (Melinda Smith, 2020), and the implementation of community mitigation measures could invariably result in negative spill over effects such as negative social behaviors, mental health issues, and others in the public, economy, political stability and social security, and become references for future planning of similar epidemics.

The Involvement of military personnel and law enforcement authorities has been observed in some countries to maintain the community discipline during lockdown. Imposing emergency law has 
created social tension in some communities and demanded protection of personal rights. Therefore, the protection of human rights along with adherence to community mitigation measures is highlighted as a future concern in pandemics like COVID-19 (Shuja et al., 2020).

The role of technological applications in disease prevention and mitigation is often discussed during the COVID-19 pandemic. GIS technology, artificial intelligence, and App-based intervention for contact tracing, patient care, and simulation exercises are novel perspectives to be incorporated into existing policies and practices (Drew et al., 2020; Kamel Boulos and Geraghty, 2020). Hence, it is essential that the application of technological innovation is incorporated into future planning, which requires international organizations to carry the process, especially in developing countries.

COVID-19 cannot be tackled alone by the health authorities. A strong and synchronized multisector approach is required with multi-disciplinary policies as its impacts extend beyond the health sector in wider scopes (Chen, Cao, and Yang, 2020).

Further, special guidelines for activities at workplaces, public places, and schools, as well as local and international travel are identified as key policy perspectives to be addressed in mitigating future events in respective nature (Anderson et al., 2020). Some guidelines such as the use of personal protective equipment (Melinda Smith, 2020), i.e., masks and gloves (Paul Glasziou and Mar, 2020) and disinfectant spraying on surfaces (Robert F., 2020) should be addressed early, and necessary guidelines should be available for similar events in the future.

In the recovery phase, the public mobility can be restricted by clustering the population according to the last digit of their National identity card number (The Government Official News Portal, 2020) and by allowing only some clusters to attend the essential services when countries decide on releasing stringent measures in place. Such measures would prevent the resurgence of cases during the pandexit. It is also necessary to maintain the public health standards, i.e., number of passengers in public transport, in reducing exposures and minimizing the spread of the disease.

\section{Medical countermeasures: diagnostic devices, therapeutic, and respiratory devices}

When a pandemic begins, it is essential to ensure the continuity of medical supply chains including PPE, ventilator, laboratory testing equipment, and reagents to respond to the surge and transmission phases in the community (Bruinen de Bruin et al., 2020). Common policy perspectives include the continuity of medical supply chains, i.e., PPE, ventilators and laboratory testing equipment and reagents and regional coordination for critical care facilities/offshore Intensive Care Units. Others involve identification of alternative production sites for the production of PPEs, e.g., garment factories, global monitoring mechanism for supply chain. All of these policy perspectives could be considered for planning mitigation of potential pandemic in the future (Bruinen de Bruin et al., 2020; Heymann et al., 2020). Pre-pandemic planning should incorporate mitigation strategies to enhance critical care capacity by improving critical care facilities, i.e., ventilators, ICU beds, and ICU information system. Health systems that are well prepared to face the extreme surge in demand can only be resilient during COVID-19 or in similar pandemics.

Regional coordination of critical care facilities and offshore ICU arrangements are alternative measures to be considered during the pandemic to lessen the overwhelming pressure on the health care systems. Besides, countries should consider all means to increase the 
production and supply of protective equipment by identifying domestic manufacturing facilities or by converting other product lines such as textile sectors into PPE suppliers to countenance the unprecedented demand during the pandemic (Heymann et al., 2020).

\section{Healthcare system preparedness and response}

Newly emergent pandemics like COVID-19 have the potential to place enormous strains on the health care system. Effective health system preparedness and response during a pandemic involve the engagement of the entire community and assert to face the increasing demand across all spectrums of care.

Success in response is strongly influenced by the extent to which such pandemics have been assessed in advance and prepared with mitigation measures. Innovative approaches for community triage and referral to healthcare institutions are essential to prioritize the care needs and allocate scarce resources fairly and transparently (Ayebare et al., 2020; Lurie et al., 2020). Moreover, a method such as the identification of population cohorts is indicated and recommended to optimize the resource allocation by considering the impacts of the deases on the population.

The common policy perspectives derived review the healthcare system preparedness and response from publicprivate partnership in providing services (Parodi and Liu, 2020), transforming health sector from patient-centred to community-centred focus (Nacoti et al., 2020) and leadership styles during the surge of cases (Hammer and Alley, 2020). A special concern should be placed for frontline staff on the supply of PPE and the chance of training especially on CBRN and on screening and diagnostic facilities for healthcare staff to work quickly (Australian Government, Department of Health, 2020). Other policy perspective are essential to look at mental health issues of frontline and key workers and the community (Shuja et al., 2020), reduction of hospital burden and hospital preparedness for surge, and strategies to minimize mobility of cases/patients-aiming to release pressure from hospitals (Litton et al., 2020). Moreover, other key perspectives in the policy making are not limited to innovative approaches for community triage and referral to healthcare institutions (Ayebare et al., 2020; Lurie et al., 2020) and investment in public health infrastructure (Walensky and Del Rio, 2020).

In general, the health care delivery system is focused on providing "patientcentered care", albeit, in pandemics, the attention is drawn towards "communitycentered care". It lies beyond the reason that pandemic solutions are imperative for the entire population, rather than for an individual patient (Nacoti et al., 2020). Therefore, policymakers need to pay attention to the barriers that arise during this transition phase and use the knowledge gained for future planning.

The intense dynamic nature of COVID-19 warrants the leaders who are responsible for efficient decision making which aligns with context specifications in responding to the COVID-19 pandemic.

The need for transformation of leadership styles provides more autonomy to local and institutional leaders to take more rational and timely decisions in cluster and community transmission phases due to the overwhelming demand on services (Hammer and Alley, 2020).

Public-private partnership in service provision is widely encouraged to respond to care needs during the pandemic as the demand surpasses the available resources and capacities in the government sector (Parodi and Liu, 2020). The fact of skilled workforce shortage is commonly identified as an urgent need to be addressed during the crisis and soon after. Thus, regular and intensive training for all health care workers is essential to promote preparedness and effectiveness in crisis management. Health authorities 
should maximize the competency of health care workers, especially the frontline staff by organizing "bridge training programs" to match the needs with specific contexts. To maintain a real-time database of the workforce with updated knowledge and skills, human resources need to be trained, and gaps in knowledge and skills are minimized. While a pool of volunteers are required during a crisis.

The risks posed by COVID-19 involve the possibility of infection and deaths. The routine care for chronic diseases and other health needs are interrupted immensely due to the prolonged progression of COVID-19. Hence, the need for inventing new models of care to continue elective care and procedures is suggested. It would reduce the hospital burden and allow hospitals to prepare for surges. Alternatives like mobile clinics and labs, medication supply systems, homecare, and outreach care minimize the virus transmission and release pressure on hospitals (Litton et al., 2020).

\section{Communication and public outreach}

Communication is vital between the government and public to raise their awareness of the current situation and to sensitize the public on their role in responding to the pandemic. Communication between the government and public, and especially vulnerable groups is a key policy perspective identified from the previous studies (Heymann et al., 2020; Igoe, 2020; Walker et al., 2020).

However, special communication strategies should be available for vulnerable and high-risk groups, i.e., elderly, minority groups, indigenous groups, patients with comorbidities, and migrants to enhance their awareness of the importance of self-protection by practicing healthy behaviors and to guide them to seek for treatment. It is important to understand the needs of the groups who often face barriers in accessing information, care, and community support and also who are at risk of confronting the secondary impacts of the pandemic in the future planning process (Heymann et al., 2020; Igoe, 2020; Walker et al., 2020).

\section{Scientific infrastructure and preparedness}

Research and development should be a vital strand of the government's strategies to mitigate COVID-19 especially as the vaccine and therapeutics development are concerned. These aspects take into account international collaboration, proactive planning and research allocation as key policy perspectives obtained ( $\mathrm{Li}$ et al., 2020; Li, Liu, and Ge, 2020; Yip et al., 2020).

As COVID-19 is a novel disease entity, it entails a variety of research to answer various questions related to it. The need for research and development for vaccines, viral genome studies, traditional medicine and diagnostics has arrived in a faster timeframe than normal one along with international collaboration, proactive planning, and sufficient resource allocation (Li et al., 2020; Li, Liu and Ge, 2020; Yip et al., 2020).

\section{Domestic and international response, global partnerships, and capacity building}

The world is on the brink of public health, economic and humanitarian crises due to the newly emergent pandemic COVID-19. There is an urgent need for policies to show national and international solidarity and government resilience during crises due to the rapid transmission of the disease beyond the borders. A mechanism should be in place to monitor and manage foreign aids during the COVID-19 pandemic, especially in developing countries to demonstrate transparency and accountability.

The common policy perspectives derived from the review are seeking all opportunities for local, national, regional and global collaboration and funding; 
strengthening the central and peripheral integrated care including municipal, provincial, territorial or indigenous jurisdictions; reducing the conflicts of policy implementation and enhancing the smooth running of public health measures; risk of developing political tension locally and regionally; policies for national and international solidarity/government resilience; foreign aid management (Simchi-Levi, Schmidt and Yehua, 2020)

World leaders should collaborate and make concerted efforts to surmount the barriers and accelerate the development, production and equitable global access to essential health care needs and technologies (Simchi-Levi, Schmidt and Yehua, 2020). At this stage, everybody should contribute to minimizing health as well as socio-economic impacts of the pandemic by using the whole of government and society approaches. A collaboration across all sectors is paramount to reduce the conflicts of policy implementations and enhance the smooth execution of public health measures.

\section{Policy perspectives during recovery of COVID-19}

In response to the COVID-19 pandemic, a huge spectrum of mitigation measures has been implemented by governments throughout the world. These measures have inevitably resulted in deleterious effects on many sectors notably on the economy (S. R. Baker et al., 2020). Therefore, almost all nations affected by COVID 19 worldwide have taken immediate actions to recover their economic conditions on different scales. Besides, other common policy perspectives found are related to microfinancing for Small and Medium Enterprises (SME); financial support for low and middle-income countries; supply chain management; sustainability through green concept; recovery of mental health needs; resuming routine healthcare services; health promotion; health system infrastructure development, investment on diagnostic, vaccine and medicine; felicitation of healthcare workers.

\section{Microfinancing for Small and Medium- sized Enterprises}

Microfinancing for Small and Medium Enterprises (SMEs) and selfemployments is a vital urgent area of emphasis in recovery. Wage subsidies, income support to households, cash flow support to businesses, investment incentives, targeted measures for affected regions and industries are some of the principles commonly used by all nations. Further, it has been suggested that governments could transfer emergency health demand to workless households to limit poverty and destitution and keep demand stimulus measures to limit the collapse in the economic activities. However, it is believed that the economic recovery should go hand in hand with social justice and decent work (Atkenson, 2020; Buheji et al., 2020; Kohlscheen, Mojon and Rees, 2020; S. Baker et al., 2020).

\section{Financial support for low- and middle- income countries}

Low- and middle-income countries need more debt relief, grants and concessional loans to effectively kick-start economic recovery. However, strong coordination between donors and development partners is the key to recover the economic downfall due to COVID 19 pandemic (Loayza and Pennings, 2020).

\section{Supply chain management}

Three different forms of the recovery have been highlighted depending on the length and the magnitude of the pandemic described in three different scenarios (Simchi-Levi, Schmidt and Yehua, 2020) Therefore, supply chain recovery and maintenance are key areas of the economic recovery that should focus on identifying exposures to risk associated with materials and suppliers, prioritize and allocate resources effectively and invest in mitigation strategies including booking 
logistic capacity. Stakeholders should develop their business recovery plans by focusing on affected suppliers and estimating time for recovery, demand, products being affected, and ways of ramping-up with operational planning and sales. However, importantly, the workforce should resume economic activities in blocks with social distancing measures during the pandexit (Armani et al., 2020; Cundell et al., 2020; Novak and Loy, 2020; Rowan and Laffey, 2020).

\section{Sustainability through a green concept}

It has been alarmed that all nations will try to boost the economy during the recovery by using more and more organic fuel, which may exacerbate global warming albeit less during the pandemic. Alternatively, governments should boost the economy under a sustainable green concept with reduced greenhouse emissions, especially under alternative energy sources to prevent a similar outbreak in the future (Williams, 2017; Climate Action Tracker, 2020). Besides, high- and middle-income countries have already focused on supporting innovations and enhancing local manufacturing to fight against COVID-19.

\section{Recovery of mental health needs}

The need for prompt actions to support and uplift the mental health needs during the pandemic is a common concern during the recovery of this unprecedented event. It is evident that mental health needs are very significant as people start to rebuild lives and cope with the impacts of the pandemic on their communities and livelihoods. Youth, elderly, women, and migrant workers are identified as vulnerable groups to face negative psychological effects during and following the incident, and thus it is required to develop interventions (Qiu et al., 2020). Health care professionals in the frontline, caring for people with confirmed or suspected COVID-19, are vulnerable to mental health problems (J. Lai et al., 2020; Zhang et al., 2020). Implementing mental health precautions parallel to the physical health precautions are essential, especially in low-income countries where scarcity of resources can cause some delays in detecting and managing mental health problems during pandemics. Apart from the mental health needs in health workers, it is required to build multisector coordination to provide effective services to improve the mental health of children (Wang et al., 2020). Government, nongovernmental organizations, community, schools and parents are the responsible partners in the process.

\section{Resuming routine health services}

It is essential to resume the routine management of chronic diseases, such as diabetes, hypertension, cardiovascular diseases, cancer, and tuberculosis, etc. Such crises have brought many restrictions to the community healthcareseeking patterns, notably among the vulnerable groups such as elderly with multi-morbidities. Since their movements have been restricted, it is necessary to reestablish regular follow-ups. According to UNICEF, the routine immunizations for kids have been interrupted due to the implementation of social distancing measures, forcing parents to skip the vaccinations (Tabish, 2020). A strong and proactive approach is required for healthcare staff COVID-19 testing during the recovery phase, and thus healthcare staff can return to work quickly. Moreover, the same approach also needs to be applied in the community to detect asymptomatic cases thus preventing a second wave (Hunter et al., 2020).

\section{Health Promotion}

We can take this catastrophe as an eye-opener to make changes in our behaviors at the individual and community levels. China is highlighting the need for detailed understanding of some risk factors such as smoking and hypertension, shown to be correlated with COVID-19 infection (Engin, Engin and Engin, 2020). 


\section{Infrastructure development}

The need for escalating the investments in acute care beds and public health capacity is identified to make the health system prepared for future incidents. The public health service system needs to be strengthened to address the future events, and the accessibility to health services needs to be improved (World Health Organization, 2020).

\section{Investment in diagnostic, vaccine, and} medicine

The world has experienced the biggest public health threat in the form of economic recession after the Spanish flu pandemic in 1918. Scientists have been working at unprecedented speed to develop diagnostics, vaccines and therapeutics for this novel coronavirus (Liu et al., 2020; Pandey et al., 2020).

\section{Felicitation}

Profound appreciation and due respect to the health workforce who have dedicatedly worked to care for affected people are essential during the recovery (Walensky and Del Rio, 2020). Not only the health care workers but also other workforces such as military forces, food supply chain providers, and sanitary workers receive felicitation for the selfless work during the pandemic.

\section{Conclusions}

In conclusion, this study has identified common policy perspectives that are imperative for the planning of a future pandemic with similar potentials. A tradeoff between stringent and smart mitigation measures was highlighted while observing bureaucracy versus individual autonomy of compliance with the measures. The spillover effects in response to the mitigation measures are deemed vital in planning future pandemic mitigation and recovery strategies. It is essential to understand the long course of the disease to prepare the seasonal variations and to assess the herd immunity of the society. Global and regional resource sharing mechanisms are vital when a universal shortage of healthcare resources occurs. Policy perspectives related to research and development are commonly identified for understanding novel pandemics and effective mitigation measures globally.

\section{Abbreviations}

COVID-19: Corona Virus Disease of 2019; SARS-CoV-2: Severe Acute Respiratory Syndrome Coronavirus 2; PPE: Personal Protective Equipment; CBRN: Chemical, Biological, Radiological and Nuclear; ICT: Information and Communication Technology; SME: Small and Medium Enterprise; ICU: Intensive Care Unit; UNICEF: United Nations International Children's Emergency Fund.

\section{Declarations}

\section{Ethics Approval and Consent Participant \\ Not Applicable}

\section{Conflict of Interest}

The authors declare that they have no conflicts of interest in this study.

\section{Availability of Data and Materials}

Data and materials can be provided upon request.

\section{Authors' Contribution}

All authors were involved in conceptualizing the article and searching literature. WIUJ drafted the manuscript, and all authors involved in manuscript editing. All authors went through the final manuscript.

\section{Acknowledgment \\ Not Applicable}




\section{References}

Anderson RM. et al. (2020) 'How will country-based mitigation measures influence the course of the $\{C O V I D\}-$ 19 epidemic?', The Lancet, 395(10228), pp. 931-934. DOI: 10.1016/S0140-6736(20)30567-5.

Armani AM. et al. (2020) 'Low-tech solutions for the COVID-19 supply chain crisis', Nature Reviews Materials. Springer US. DOI: 10.1038/s41578-020-0205-1.

Atkenson A (2020) 'What Will Be The Economic Impact of COVID-19 in the US?', NBER Working Paper Series, 53(9), pp. 1689-1699. DOI: 10.1017/CBO9781107415324.004.

Australian Government, Department of Health (2020) Coronavirus advice for the health and aged care sector. Available at: https://www.health.gov.au/news/heal th-alerts/novel-coronavirus-2019ncov-health-alert/coronavirusCOVID-19-advice-for-the-healthand-aged-care-sector\#usingpersonal-protective-equipment-ppe (Accessed: 19 May 2020).

Ayebare RR. et al. (2020) 'Adoption of COVID-19 triage strategies for lowincome settings', The Lancet Respiratory Medicine. Elsevier Ltd, 8(4), p. e22. DOI: 10.1016/S22132600(20)30114-4.

Baker S. et al. (2020) 'COVID-Induced Economic Uncertainty', National Bureau of Economic Research. DOI: 10.3386/w26983.

Baker SR. et al. (2020) 'Covid Economics Vetted and Real-Time Papers', Covid Economics, 1(3).

Bruinen de Bruin $Y$, Lequarre A-S, McCourt J, Clevestig P, Pigazzani F,
Zare Jeddi M, et al. Initial impacts of global risk mitigation measures taken during the combatting of the COVID-19 pandemic. Saf Sci [Internet]. 2020;128:104773. Available from: http://www.sciencedirect.com/scienc e/article/pii/S0925753520301703

Buheji M. et al. (2020) 'The Extent of COVID-19 Pandemic SocioEconomic Impact on Global Poverty. A Global Integrative Multidisciplinary Review', American Journal of Economics, 2020(4), pp. 213-224. DOI:

10.5923/j.economics.20201004.02.

Chen Z, Cao C. and Yang G. (2020) 'Coordinated multi-sectoral efforts needed to address the COVID-19 pandemic: lessons from China and the United States', Global health research and policy. BioMed Central, 5, p. 22. DOI: 10.1186/s41256-02000150-7.

Climate Action Tracker (2020) 'A government roadmap for addressing the climate and post COVID-19 economic crises', (April). Available at:

https://climateactiontracker.org/docu ments/706/CAT_2020-04-

27_Briefing_COVID19_Apr2020.pdf.

Crubézy E. and Telmon N. (2020) 'Pandemic-related excess mortality (COVID-19), public health measures and funerary rituals', EClinicalMedicine. The Authors. Published by Elsevier Ltd., p. $100358 . \quad$ DOI: 10.1016/j.eclinm.2020.100358.

Cundell AM. et al. (2020) 'Controls To Minimize Disruption of the Pharmaceutical Supply Chain During the COVID-19 Pandemic.', PDA journal of pharmaceutical science and technology. DOI: 10.5731/pdajpst.2020.012021. 
Desjardins MR., Hohl A. and Delmelle EM. (2020) 'Rapid surveillance of COVID-19 in the United States using a prospective space-time scan statistic: Detecting and evaluating emerging clusters', Applied geography (Sevenoaks, England). 2020/04/08. The Authors. Published by Elsevier Ltd., 118, p. 102202. DOI:

10.1016/j.apgeog.2020.102202.

Douglas M. et al. (2020) 'Mitigating the wider health effects of COVID-19 pandemic response', BMJ, 369, p. m1557. DOI: 10.1136/BMJ.m1557.

Drew DA. et al. (2020) 'Rapid implementation of mobile technology for real-time epidemiology of COVID19', Science (New York, N.Y.). American Association for the Advancement of Science, $p$. eabc0473. DOI:

10.1126/science.abc0473.

Ebrahim SH. et al. (2020) 'COVID-19 and community mitigation strategies in a pandemic.', $\quad\{B M J\} \quad$ (Clinical Research Ed.), 368, p. m1066. doi: 10.1136/bmj.m1066.

Engin AB., Engin, E. D. and Engin, A. (2020) 'Two important controversial risk factors in SARS-CoV-2 infection: Obesity and smoking', Environmental toxicology and pharmacology. Elsevier B.V., 78, p. 103411.

DOI: 10.1016/j.etap.2020.103411.

Hammer L. and Alley L. (2020) 'Essential leadership skills during coronavirus pandemic'. Available at: https://www.fastcompany.com/90494 094/this-is-the-most-essential-skillleaders-need-to-work-through-theCOVID-19-crisis (Accessed: 19 May 2020).
Heymann DL. et al. (2020) '\{COVID\}-19: what is next for public health?', The Lancet, 395(10224), pp. 542-545. DOI: $10.1016 / S 0140-$ 6736(20)30374-3.

Hunter E. et al. (2020) 'First experience of COVID-19 screening of health-care workers in England', The Lancet. Elsevier Ltd, 395(10234), pp. e77e78. DOI: 10.1016/S01406736(20)30970-3.

Igoe KJ. (2020) 'Developing Public Health Communication Strategies, and Combating Misinformation during COVID-19'. Available at: https://www.hsph.harvard.edu/ecpe/ public-health-communicationstrategies-COVID-19/ (Accessed: 19 May 2020).

John Hopkins University of Medicine (2020) COVID-19 Map, John Hopkins University. Available at: https://coronavirus.jhu.edu/map.html (Accessed: 21 May 2020).

Kamel Boulos MN. and Geraghty EM. (2020) 'Geographical tracking and mapping of coronavirus disease COVID-19/severe acute respiratory syndrome coronavirus 2 (SARSCoV-2) epidemic and associated events around the world: how 21st century GIS technologies are supporting the global fight against outbr', International Journal of health geographics. BioMed Central, 19(1), p. 8. DOI: 10.1186/s12942-02000202-8.

Kohlscheen E, Mojon B. and Rees D. (2020) 'The Macroeconomic Spillover Effects of the Pandemic on the Global Economy', SSRN Electronic Journal, (4). DOI: 10.2139/ssrn.3569554.

Lai J. et al. (2020) 'Factors Associated With Mental Health Outcomes 
Among Health Care Workers Exposed to Coronavirus Disease 2019', JAMA network open. American Medical Association, 3(3), pp. e203976-e203976. DOI: 10.1001/jamanetworkopen.2020.397 6.

Lai S. et al. (2020) 'Effect of nonpharmaceutical interventions to contain COVID-19 in China.', Nature. Springer US. DOI: 10.1038/s41586020-2293-x.

Lasry A. et al. (2020) 'Timing of Community Mitigation and Changes in Reported COVID-19', Morbidity and Mortality Weekly Report, 69(15), pp. 1-7.

Li H. et al. (2020) 'Coronavirus disease 2019 (COVID-19): current status and future perspectives', International Journal of antimicrobial agents. 2020/03/29. Elsevier B.V. and International Society of Chemotherapy., 55(5), p. 105951. DOI: 10.1016/j.jjantimicag.2020.105951.

Li H, Liu Z. and Ge J. (2020) 'Scientific research progress of COVID19/SARS-CoV-2 in the first five months', Journal of cellular and molecular medicine. John Wiley and Sons Inc., p. 10.1111/jcmm.15364. DOI: $10.1111 / \mathrm{jcmm} .15364$.

Litto, E. et al. (2020) 'Surge capacity of intensive care units in case of acute increase in demand caused by COVID-19 in Australia', The Medical Journal of Australia. 2020/04/19. John Wiley and Sons Inc., 212(10), pp. 463-467. DOI: $10.5694 / \mathrm{mja} 2.50596$.

Liu C. et al. (2020) 'Research and Development on Therapeutic Agents and Vaccines for COVID-19 and
Related Human Coronavirus Diseases', ACS central science. 2020/03/12. American Chemical Society, 6(3), pp. 315-331. DOI: 10.1021/acscentsci.0c00272.

Loayza NV and Pennings S. (2020) 'Research \& Policy Briefs Macroeconomic Policy in the Time of COVID-19: A Primer for Developing Countries', (28).

Lurie N. et al. (2020) 'Developing COVID19 Vaccines at Pandemic Speed', New England Journal of Medicine, pp. 1973-1975. DOI: 10.1056/nejmp2005630.

Madhav N. et al. (2017) 'Pandemics: risks, impacts, and mitigation', in Jamison, D. T. et al. (eds) Disease control priorities: improving health and reducing poverty. 3rd edn. Washington ( $\{D C\})$ : The International Bank for Reconstruction and Development / The World Bank. DOI: $\quad$ 10.1596/978-1-4648-05271_ch17.

Melinda Smith MALR. (2020) Coronavirus Anxiety: Coping with Stress, Fear, and Worry, HelpGuide. Available at: https://www.helpguide.org/articles/an xiety/coronavirus-anxiety.htm (Accessed: 20 May 2020).

Nacoti M. et al. (2020) 'At the Epicenter of the COVID-19 Pandemic and Humanitarian Crises in Italy: Changing Perspectives on Preparation and Mitigation', Catalyst non-issue content, 1(2). Available at: https://catalyst.nejm.org/doi/abs/10.1 056/\%7BCAT\%7D.20.0080

(Accessed: 19 May 2020).

Nova Scotia Health Authority (2020) AT THE READY COVID-19 Planning and Response, Nova Scotia Health Authority. Available at: http://www.nshealth.ca/sites/nshealt 
h.ca/files/nshas_COVID-

19_planning_and_response.pdf

(Accessed: 24 May 2020).

Novak JI. and Loy J. (2020) 'A critical review of initial 3D printed products responding to COVID-19 health and supply chain challenges', Emerald Open Research, 2, p. 24. DOI: 10.35241/emeraldopenres.13697.1.

Nsubuga P, White ME, T. S. (2006) Public Health Surveillance: A Tool for Targeting and Monitoring Interventions. 2nd edn. Edited by $\mathrm{M}$. A. Jamison DT, Breman JG. Washington (DC): The World Bank. Available at: https://www.ncbi.nlm.nih.gov/books/ NBK11770.

Nunes-vaz, R. (2020) 'Visualising the doubling time of COVID-19 allows comparison of the success of containment measures', Global Biosecurity, 1(March), pp. 1-4.

Pandey A. et al. (2020) 'Potential therapeutic targets for combating SARS-CoV-2: Drug repurposing, clinical trials and recent advancements', Life Sciences. Elsevier Inc., p. 117883. DOI: 10.1016/j.lfs.2020.117883.

Parodi SM. and Liu VX. (2020) 'From Containment to Mitigation of \{COVID\}-19 in the \{US\}.', The Journal of the American Medical Association.

DOI:

10.1001/jama.2020.3882.

Paul G and Mar C. Del (2020) Should everyone be wearing face masks? It's complicated, THE CONVERSATION. Available at: https://theconversation.com/shouldeveryone-be-wearing-face-masksits-complicated-135548 (Accessed: 4 May 2020).
Qiu J. et al. (2020) 'A nationwide survey of psychological distress among Chinese people in the COVID-19 epidemic: implications and policy recommendations.',

General Psychiatry, 33(2), p. e100213. DOI: 10.1136/gpsych-2020-100213.

Radwanski A. and Semeniuk I. (2020) 'What will Canadaltextquoterights Pandexit strategy look like? How officials are deciding when to lift coronavirus lockdowns', The globe and mail. Available at: https://www.theglobeandmail.com/ca nada/article-what-will-canadaspandexit-strategy-look-like-howofficials-are/ (Accessed: 19 May 2020).

Robert F. (2020) 'Does disinfecting surfaces really prevent the spread of coronavirus?', Science. DOI: doi:10.1126/science.abb7058.

Rowan NJ. and Laffey JG. (2020) 'Challenges and solutions for addressing critical shortage of supply chain for personal and protective equipment (PPE) arising from Coronavirus disease (COVID19) pandemic - Case study from the Republic of Ireland', Science of the Total Environment. The Authors, 725, p. 138532. DOI: 10.1016/j.scitotenv.2020.138532.

Shearer FM. et al. (2020) 'Infectious disease pandemic planning and response: Incorporating decision analysis', PLoS Medicine. Public Library of Science, 17(1), pp. e1003018-e1003018. DOI: 10.1371/journal.pmed.1003018.

Shuja KH. et al. (2020) '\{COVID\}-19 Pandemic and Impending Global Mental Health Implications.', Psychiatria Danubina, 32(1), pp. 3235. DOI: $10.24869 /$ psyd.2020.32. 
Simchi-Levi, D, Schmidt, W. and Yehua, W. (2020) From Superstorms to Factory Fires: Managing Unpredictable Supply-Chain Disruptions, Harvard Business Review Home. Available at: https://hbr.org/2014/01/fromsuperstorms-to-factory-firesmanaging-unpredictable-supplychain-disruptions (Accessed: 28 April 2020).

Tabish SA. (2020) 'Calm before storm', International Journal of Science and Research (IJSR), 9, pp. 175-179. DOI: 10.21275/SR20403184133.

The Government Official News Portal (2020) Permission to go out for essential requirements based on last digit of ID card, The Government Official News Portal. Colombo. Available at: https://news.Ik/news/political-currentaffairs/item/30036-permission-to-goout-for-essential-requirementsbased-on-last-digit-of-id-card (Accessed: 20 May 2020).

The Organisation for Economic Cooperation and Development (2020) 'Flattening the COVID-19 peak: Containment and mitigation policies Flattening the COVID-19 peak: Containment and mitigation policies', (March), pp. 1-27. Available at: https://read.oecdilibrary.org/view/?ref=124_124999yt5ggxirhc\&title=Flattening_the_CO VID-19_peak-

Containment_and_mitigation_policie s.

U.S. Department of Health and Human Services (HHS) (2017) 'Pandemic Influenza Plan - 2017 Update', Office of the Assistant Secretary for Preparedness, HHS. Available at: https://www.cdc.gov/flu/pandemicresources/pdf/pan-flu-report2017v2.pdf.
Verboom B, Montgomery P. and Bennett S. (2016) 'What factors affect evidence-informed policymaking in public health? Protocol for a systematic review of qualitative evidence using thematic synthesis', Systematic Reviews. Systematic Reviews, 5(1), pp. 1-9. DOI: 10.1186/s13643-016-0240-6.

Walensky RP. and Del Rio C. (2020) 'From Mitigation to Containment of the \{COVID\}-19 Pandemic: Putting the $\{\mathrm{SARS}\}-\{\mathrm{CoV}\}-2$ Genie Back in the Bottle.', The Journal of the American Medical Association. DOI: 10.1001/jama.2020.6572.

Walker P. et al. (2020) 'Report 12: The global impact of \{COVID\}-19 and strategies for mitigation and suppression', Imperial College London. DOI: 10.25561/77735.

Wang G. et al. (2020) 'Mitigate the effects of home confinement on children during the COVID-19 outbreak', The Lancet, 395(10228), pp. 945-947. DOI: $\quad 10.1016 / S 0140-$ 6736(20)30547-X.

Weible CM. et al. (2020) 'COVID-19 and the policy sciences: initial reactions and perspectives', Policy Sciences. Springer US. DOI: 10.1007/s11077020-09381-4.

Williams (2017) 'Transforming Economies and Generating Sustainable "Green" Economic Growth After the COVID19 Pandemic through General Collective Intelligence', Journal of Chemical Information and Modeling, 53(9), pp. 1689-1699. DOI: 10.1017/CBO9781107415324.004.

Wirth T. (2018) 'Globalization and infectious diseases', Biodiversity and Evolution, (3), pp. 123-137. DOI: 
10.1016/B978-1-78548-277-

9.50008-5.

Wong, VC. et al. (2020) 'The role of community-wide wearing of face mask for control of coronavirus disease 2019 (COVID-19) epidemic due to SARS-CoV-2', Journal of Infection, (January).

World Health Organization (2020) Report of the $\{W H O\}-C h i n a$ Joint Mission on Coronavirus Disease 2019 (\{COVID\}-19). World Health Organization. Available at: https://www.who.int/docs/defaultsource/coronaviruse/who-china-jointmission-on-COVID-19-finalreport.pdf (Accessed: 19 May 2020).
Yip CCY. et al. (2020) 'Development of a Novel, Genome Subtraction-Derived, SARS-CoV-2-Specific COVID-19nsp2 Real-Time RT-PCR Assay and Its Evaluation Using Clinical Specimens', International journal of molecular sciences. MDPI, 21(7), p. 2574. DOI: 10.3390/ijms21072574.

Zhang WR. et al. (2020) 'Mental Health and Psychosocial Problems of Medical Health Workers during the COVID-19 Epidemic in China', Psychotherapy and Psychosomatics, 100053(45).

DOI: 